International Journal of Canadian Studies

Revue internationale d'études canadiennes

NTERNATIONAL JOURNAL OF CANADIAN STUDIES

REYUE INTERNATIONALE D'ÉTUDES CANADIENNES

\title{
Citizenship and Health Care in Canada
}

\section{Antonia Maioni}

Numéro 42, 2010

Canadian Issues: childhoods, states, nationalisms

Enjeux canadiens : enfances, États, nationalismes

URI : https://id.erudit.org/iderudit/1002179ar

DOI : https://doi.org/10.7202/1002179ar

Aller au sommaire du numéro

\section{Éditeur(s)}

Conseil international d'études canadiennes

ISSN

1180-3991 (imprimé)

1923-5291 (numérique)

Découvrir la revue

Citer cet article

Maioni, A. (2010). Citizenship and Health Care in Canada. International Journal of Canadian Studies / Revue internationale d'études canadiennes, (42), 225-242. https://doi.org/10.7202/1002179ar
Résumé de l'article

La relation entre la citoyenneté et la politique sociale occupe une place importante dans l'évolution de la gouvernance d'après-guerre au Canada et ailleurs dans le monde. Les soins de santé sont sans doute l'exemple par excellence de la façon dont les programmes sociaux du gouvernement peuvent renforcer la citoyenneté et la légitimité de l'État, et établir, entre les citoyens, les limites du consensus social ainsi que des droits et responsabilités mutuels. Dans la plupart des États-providence modernes, il est évident que les politiques sociales favorisent les régimes de citoyenneté et que le respect des engagements suscite forcément des tensions. Le cas du Canada est l'un des plus curieux. Cet article examine de plus près la combinaison anormale d'une gouvernance provinciale forte qui coexiste avec un processus plus centralisé de construction de la nation au Canada. L'auteur y étudie tous les aspects du développement des soins de santé au Canada à travers l'optique d'analyse de l'interface entre la gouvernance fédérale et provinciale d'une part, et la difficulté que continue de poser la prise de décisions relatives à la réforme de la santé d'autre part.
All Rights Reserved (C) Conseil international d'études canadiennes, 2010

Ce document est protégé par la loi sur le droit d'auteur. L'utilisation des services d'Érudit (y compris la reproduction) est assujettie à sa politique d'utilisation que vous pouvez consulter en ligne.

https://apropos.erudit.org/fr/usagers/politique-dutilisation/ 


\title{
Antonia Maioni
}

\section{Citizenship and Health Care in Canada}

\begin{abstract}
The link between citizenship and social policy occupies an important space in the development of postwar governance in Canada and elsewhere. And health care represents perhaps the most important example of the way in which government social programs can enhance citizenship and state legitimacy, and establish the boundaries of social consensus and mutual rights and responsibilities between citizens. The impact of social policies in promoting citizenship regimes and the tensions inherent in sustaining the commitments are evident in most modern welfare states. The case of Canada is one of the most intriguing. This article looks in more detail at the anomalous combination of strong provincial governance that co-exists with a more centralized nation-building process in Canada. It explores the development of health care in Canada through the lens of the interface between federal and provincial governance and the kinds of challenges in decision-making that persist in health reform today.
\end{abstract}

\section{Résumé}

La relation entre la citoyenneté et la politique sociale occupe une place importante dans l'évolution de la gouvernance d'après-guerre au Canada et ailleurs dans le monde. Les soins de santé sont sans doute l'exemple par excellence de la façon dont les programmes sociaux du gouvernement peuvent renforcer la citoyenneté et la légitimité de l'État, et établir, entre les citoyens, les limites du consensus social ainsi que des droits et responsabilités mutuels. Dans la plupart des États-providence modernes, il est évident que les politiques sociales favorisent les régimes de citoyenneté et que le respect des engagements suscite forcément des tensions. Le cas du Canada est l'un des plus curieux. Cet article examine de plus près la combinaison anormale d'une gouvernance provinciale forte qui coexiste avec un processus plus centralisé de construction de la nation au Canada. L'auteur y étudie tous les aspects du développement des soins de santé au Canada à travers l'optique d'analyse de l'interface entre la gouvernance fédérale et provinciale d'une part, et la difficulté que continue de poser la prise de décisions relatives à la réforme de la santé d'autre part.

When Canadians are asked what sets them apart from Americans, a substantial number invariably mention the health care system as a distinctive feature of Canadian identity (National Forum on Health, 1997). Most Canadians have come to consider health care, in common parlance, a right of citizenship. Even though the division of powers in the Constitution Act, 1867, suggests that health care is a provincial responsibility, the dynamics of fiscal federalism and 
the presence of the Canada Health Act reinforce the symbolic link between being "Canadian" and being a recipient of health care services. Indeed, the principles outlined in the legislation (accessibility, comprehensiveness, portability, public administration, and universality) are considered the "norms" of the health care system. In particular, the emphasis on universal coverage, equal access, and portable benefits has come to define the citizenship dimensions of health care provision in Canada.

The link between citizenship and social policy occupies an important space in the development of postwar governance in Canada and elsewhere. Much of the literature on the welfare state is steeped in the premise of the "rights" of citizenship that came to include not only civil and political rights, but social rights as well (Marshall). As Jane Jenson has argued, provisions for health, education, and unemployment could be used to forge a "social citizenship" to temper the realities of class conflict in industrial capitalism.

In Canada, the seminal impact of the Beveridge Report-with its essential idea of a "social security" state - also found resonance in the Marsh Report and the discussion of postwar reconstruction that linked "freedom and opportunity" with income security and the provision of social services (Marsh). Although the postwar welfare state would be slower to develop in Canada than elsewhere, the essential notion of that linkage between state provision and social citizenship remains embedded in the publicly funded health care programs that have developed across the provinces (Maioni, "New Century").

Health care represents perhaps the most important example of the way in which government social programs can enhance citizenship and state legitimacy. Through its involvement in health care, the modern state takes on a crucial role in social protection in the sense of literally "protecting" its citizens from the effects of ill health. In helping to finance the provision of health care services, governments offset the potentially catastrophic costs associated with illness. In regulating the health care sector, governments shape the rules of the fundamental relationship between providers and patients. In essence, involvement in health care represents a way in which the state can help establish the boundaries of social consensus and mutual rights and responsibilities between citizens.

In Canada, three tenets that shaped the postwar welfare state that can be seen in health care arrangements (Maioni, "Ideology"). The first is the liberal ideal of the state as "regulator" of public goods and the commitment to equality of opportunity. Added to this are the social-democratic tenets of solidarity and universality, allowing for contribution based on ability, and access based on need. Finally, the design of health care in Canada has reflected a commitment to collective responsibility and to the bonds of community in a 
diverse society. In fact, no other government programme is quite so "universal" as provincial health care systems: everyone has access, on equal terms and conditions, without taking into account gender, race, language, ethnic group, or income.

For the same reason, however, health care places an enormous responsibility on the modern state, one that many governments are finding difficult to sustain. Precisely because health care is arguably one of the most potent of social services - the most personal in its impact, the most direct in its reach, and the most expensive for payers - it is also the service sector in which governments are most vulnerable to the effects of citizen involvement, participation, and feedback. As consumers of care, citizens are directly affected by changes in delivery and financing, leading to mobilization against governments that engage in reform.

But because health care is a service provided by highly specialized professionals in increasingly complex technological and administrative settings, the linkage — and accountability — between state and citizen is often less than transparent. Moreover, because health care does not follow the normal supply and demand patterns associated with typical consumer goods (Evans), governments are attempting to regulate an industry for which outcomes - namely "better health" - are difficult to quantify; where the relationship between supply and demand is affected by professional expertise; and where the inflationary potential in life-threatening situations may be practically limitless. This raises substantial political risks, puts enormous pressure on public funds, and provides the potential for lucrative private-sector alternatives.

The impact of social policies in promoting citizenship regimes and the tensions inherent in sustaining the commitments are evident in most modern welfare states. The case of Canada, however, is one of the most intriguing. In the Canadian experience, health care has been heralded as a singular achievement of what states and citizens can do best together: effecting regulation and pooling resources in an effort to ensure universal and comprehensive health care provision based on need rather than ability to pay. Because Canada is a federal polity in which social protection is considered primarily in the purview of sub-national governments, the "success" of health care policy can also be considered an example of how decentralized governance can co-exist with the promotion of a shared sense of national identity. Some have argued that federal involvement in social policy has been used in Canada as a form of citizenship building through "national integration" and as an instrument of legitimization by the federal government vis-à-vis the provinces (Banting, "The Welfare State"). More recently, the relationship between social policy and nationalism in competitive multinational settings - such Canada and Quebec - has shed insight into the nature of solidarity and redistribution as a basis for identity (Béland and Lecours). 
This article looks in more detail at this anomalous combination of strong "local" (i.e., provincial) governance that co-exists with a more centralized nation-building process in Canada. It explores the development of health care in Canada through the lens of the interface between federal and provincial governance and the kinds of challenges in decision-making that persist in health reform today.

\section{The Development of Health Policy in Canada}

Canada has two governance features that make its health care experience unusual. Although Canada is usually classified as a "liberal" welfare state (Esping-Andersen), historically dominated by the needs of a market economy, provincial health care systems are imbued with social democratic principles. The Canadian health care system combines elements of a "liberal" ideology (in that doctors and hospitals are independent of direct state control) and a more "social democratic" vision (in that health care services are publicly financed and the state ensures equal access to these services).

The second feature is federalism. As a political arrangement, federalism is usually considered problematic in the development of social protection. Division of power tends to diffuse responsibility-and decisive actionthat allows politicians to fall into "joint decision traps" (Scharpf) and the opportunity to engage in "blame avoidance" and other strategies to offset accountability (Weaver). In effect, a divided and decentralized polity opens up additional sets of "veto points" to concerted state action (Immergut). Again, the Canadian experience in health care is exceptional in this regard. Provincial experimentation spurred the most significant developments in health policy in Canada, while activist federal governments carved out a fiscal and political policy space to ensure similar health care coverage for Canadian citizens regardless of their province of residence (Tuohy). In this sense, the federal system of governance in Canada opened "multiple independent action points" useful to health care reformers (Banting, "The Welfare State").

Both of these governance features played a role in the development of health policy in Canada. Intergovernmental conflict initially delayed the process of health policy development, but decentralization also encouraged provincial experimentation and led to the innovations that became the basis of public health insurance throughout Canada. A social democratic provincial party, the CCF (later the NDP) in Saskatchewan, inaugurated the first government-sponsored hospital insurance (in 1947) and medical insurance (in 1962) in North America. The success of these innovations combined with the political pressure exerted by the party's federal wing were pivotal in spurring activists within the national Liberal party to develop cost-sharing programs in hospital insurance (under the Hospital and Insurance and Diagnostic Services Act, 1957) and medical care (under the Medical Care Insurance Act, 1966). 
The goal was to ensure that Canadian taxpayers' money would be used to help finance publicly accountable health insurance systems that ensured the same basic social protection among Canadian citizens, regardless of their province of residence. An additional idea was implicit in this health care model: social benefits, including health benefits, could contribute to regional equity in Canada and reflected a "common Canadian citizenship" (Banting, "The Past Speaks"). Not all provincial governments were convinced by these arguments: the Social Credit government in Alberta, for example, resisted this social-democratic import, favouring instead voluntary health insurance, dubbed "Manningcare" for Premier Ernest Manning; nor were all Canadians convinced, either, as parts of the medical profession showed in their strike action in Saskatchewan and, later, Quebec.

In Quebec, there was initial resistance to federal "interference" in the form of cost sharing for both hospital and medical care insurance. The resistance to hospital insurance had been based on the Union Nationale government's aversion to secular, state, and federal intervention in societal issues. The arrival in power of the Liberal party in 1960, led by former federal minister Jean Lesage, and transformed by its association with labour and liberalism signalled an important political shift in thinking about the role of the Quebec state. One of the Lesage governments' first actions was to sign on to the federal hospital insurance cost-sharing agreement, marking an important milestone in the "Quiet Revolution" of economic, social, and political change in the province (Facal). Medical insurance would prove to be an even more complex policy experiment in Quebec, as the Liberal government clashed with medical specialists over the implantation of a unique health and social services system (Castonguay).

Since the advent of hospital and medical insurance across the Canadian provinces, governance issues in health policy have developed in seemingly contradictory fashion. On the one hand, there has been substantial "decentralizing" of fiscal responsibility for health care over the past few decades; on the other hand, at least until 2006, a commitment to preserving and in some cases, expanding, federal "political space" in the health care sector.

Almost immediately after the ink had dried on cost-sharing agreements with the provinces, successive federal governments, both Liberal and Conservative, attempted to reduce the federal share in funding the costs of health care, in what was often perceived as a unilateral fashion. In 1977, the Established Programs Financing Act (EPF) replaced cost sharing with block funding (partly cash, partly tax points) based on population and tied to the rate of growth of GNP. This was subsequently restricted to GNP increases less 2 percentage points in the 1985 budget, and essentially frozen after the economic shocks of 1990 (Smith and Maioni). As the changes in the funding formula led to decreases in health transfers to the provinces, the Conservative 
government effectively devolved the responsibility to exercise restraint and control health care expenditures to the provinces; some critics also pointed out that the federal government was "off-loading" its deficit problems to the provinces (Boothe and Johnson). The Liberal government returned to power with the overriding goal of "slaying the deficit." A central feature of its strategy was to replace the EPF arrangement, along with the existing cost-shared Canada Assistance Plan, with a new Canada Health and Social Transfer (CHST) that would consolidate federal transfers. But the CHST substantially reduced the cash portion of federal transfers to the provinces. While in the mid-1970s, federal transfers accounted for almost 40 percent of provincial health expenditures, by the mid-1990s, they represented one-third of provincial outlays in health care (CIHI). Therefore, federal budget imperatives, buttressed by financial markets and political pressure, profoundly affected provincial capacities to finance, and budget for, health care spending.

As the economic situation alleviated, the 1999 federal budget allocated a further $\$ 28.4$ billion to help fund provincial social programs, including health care. In 2003, the Canada Health Transfer (CHT) came into effect, with increased funding provided through a Health Reform Fund intended to fund targeted initiatives (Primary Health Care, Home Care, Catastrophic Drugs, and Diagnostic/Medical Equipment) that had been highlighted in the Romanow report (Commission, 2002).

However, it was not until the fall of 2004 that the Liberal government, under the new leadership of Prime Minister Paul Martin but in a tight minority situation in the House of Commons, was willing to come to the table with the provincial premiers with guaranteed multi-year funding increases. After extensive negotiations, the First Ministers reached an agreement for a tenyear plan for increased health care transfers and a special fund to reduce waiting times, which had become a thorny political issue. In all, the federal government estimated this would inject $\$ 41$ billion into health care across Canada (Maioni, "Health Care").

While this initiative gave some policy latitude and fiscal security to the provinces, it still echoed what federal governments - or at least Liberal governments - had been seeking to do for several years: expanding a political space in the health realm and, in so doing, attempting to reinforce the sense of a direct linkage between citizenship and health care provision. For example, Prime Minister Jean Chretien, even in the midst of fiscal crisis and funding cuts of the $1990 \mathrm{~s}$, repeatedly took on the moral authority to protect the citizenship aspects of health care provision despite (or perhaps because of) the fact that health care delivery and financing remains the jurisdiction of provincial governments. In 1997 and again in 2002, he introduced two reports - the National Forum on Health and the Commission on the Future of Health Care - that reinforced this sentiment and its consequences. 
Another example of place-setting is the federal government's role in public health and health promotion; from the 1974 Lalonde Report (which focused on public health in terms of lifestyle and environment) to more aggressive anti-tobacco policies in the 1990s, the federal government has taken on a stewardship role to ensure the "healthiness" of Canadians. More recently, leadership on the part of the federal government has been propelled by the need for coordination and collaboration in areas in which health "has no borders": namely, public health, infectious disease, and pandemics. During the summer of 2003, the SARS flu, a highly contagious viral illness, spread quickly through Toronto-area hospitals. Attempts to address the 2003 SARS crisis in Toronto, for example, had a ripple effect throughout the country and led to calls for a more coordinated approach to planning for and dealing with such problems. The taskforce investigating the epidemic cited the need for better intergovernmental coordination, and a more collaborative framework for public health (Naylor). The Canadian Public Health Agency that was put into place by the federal government in 2004 has tried to ensure federal leadership in this area, but it still by necessity involved in a complex coordination dance with the provinces - and territories. The recent preparedness response to the H1N1 pandemic is a case in point: while the federal government secured the supply and distribution of the vaccine and attempted to spearhead public communications, this did not always correspond smoothly with health care delivery on the ground in the provinces.

The health of First Nations and Aboriginal groups is also an unresolved issue in the "citizenship" debate about health care in Canada. While the federal government does have constitutional responsibilities for the general welfare of specific classes of people, including "Indians," provincial health care systems tend to service these populations, either through arrangements with the federal and Aboriginal governments to supply services on-reserve, or through the access of care by individuals Aboriginals who live in nonreserve settings, usually urban centres.

\section{The Canada Health Act}

From a simple statute, the Canada Health Act has come to symbolize something far more grand and compelling. On paper, this 1984 legislation is an act of Parliament amalgamating existing federal hospital and medical insurance legislation and stipulating the principles provincial health systems should respect in order to avoid financial penalties. In practice, however, the Canada Health Act allocates a prominent place for the federal government in the health policy environment and, symbolically, in Canadians' perceptions of the health care system.

The origins of the Canada Health Act can be seen to reflect that institutional conundrum of Canadian health politics: between provincial governance 
and the federal purse. Although the provinces became responsible for health care cost increases after the introduction of block grants in 1977, the federal government continued to exert an influence in health policy through the conditions attached to the cash component of fiscal transfers. The complexity of the intergovernmental financing arrangements contributed to a lack of transparency and accountability as each level of government blamed the other: the provincial governments claimed that the federal government was underfunding the system while the federal government claimed that the provinces were diverting the money to other uses (Badgely 51-52). In 1979, the Conservative government of Joe Clark asked Emmett Hall to head a commission of inquiry into the situation. While the "diversion" of health transfers to other uses by provinces was discounted, the commission did find evidence of financial pressures that opened the door to user fees in some provinces and an increase in extra billing by doctors (Taylor).

Both extra billing and user fees undermined confidence in the reasonable access to care that had underpinned the spirit of the original cost-sharing agreements. As federal bureaucrats discovered, neither the hospital and medical insurance legislation nor the block grants provided a formula for the federal government to enforce conditionality. Under EPF, the tax point portion of federal funding transferred to the provinces and could not be "taken back" by the federal government. Although, in principle, the cash grant portion of the grant could be withheld, in practice, the only way to bring pressure to bear on recalcitrant provinces would be to withhold the entire cash grant portion of the transfer, a measure that was not only a disproportionate penalty but which would also throw provincial health care financing into chaos.

The political confrontation that ensued in the early 1980s involved provincial governments that balked at the spectre of more federal intrusion and the vocal opposition of medical professionals against state interference in their private practice. Despite this uproar, in a dramatic gesture, Liberal Prime Minister Pierre Trudeau reinforced the federal government's political stake in health care with the Canada Health Act of 1984. Ostensibly directed at ensuring equal access to health services by eliminating the practice of "extra billing" by physicians, it amalgamated hospital and medical legislation into a single, visible, and highly symbolic federal statute. Although the Liberal party went down to defeat shortly after its passage, the Canada Health Act retained its symbolic appeal: even though the Progressive Conservative government attempted to scale back social programs (with mixed results), Prime Minister Brian Mulroney publicly stated that health care remained a "sacred trust" of the Canadian government.

The Canada Health Act's primary emphasis was to establish the standards by which cash contributions from the federal government are transferred to the provinces in order to help fund insured services provided by provincial health 
care plans. For a province to receive the full amount it is due, it must satisfy the five basic principles described in Sections 8 to 12 (public administration, comprehensiveness, universality, portability, and accessibility). While these broad principles existed in previous medical insurance legislation, the CHA emphasizes that the "primary objective" of federal involvement is to "facilitate reasonable access to health services without financial or other barriers," meaning essentially that every citizen has the same ability to access the health care system. In order to do this, the CHA is very specific about the standards to which provinces will be held: namely, no extra billing and no user fee imposition.

To defenders of public health insurance, this remains essential because the use of deterrent charges violates the principle of equal access, while extra billing allows physicians to play by two sets of rules and pump extra costs into the health care system (Evans, "Tension, Compression"). For some provincial governments, however, the CHA represented an over-stepping of federal power in this area of provincial jurisdiction. Nevertheless, with the spectre of federal sanctions, provinces were persuaded to ban user fees and extra billing (except in Quebec, where such bans were already in effect), although in the case of Ontario, the medical association was not easily persuaded and specialists went on strike (Tuohy).

Despite the emphasis on rules, the CHA has no institutionalized process for consultation or dispute resolution between the federal government and the provinces. The mechanism governing this process works, in theory, in a bilateral fashion but in practice resembles more a unilateral process in which decisions are made by the federal government. Each province is required to submit an annual report - including a financial statement - that details how its health care plan conforms to CHA principles. Under section 14 of the $\mathrm{CHA}$, if the federal minister of health decides that a provincial health care plan has "ceased to satisfy any one of the criteria," he or she is empowered to report to the Cabinet and direct the finance department to make deductions from transfer payments. The existence of extra billing is usually obvious, but the user fee question is sometimes less straightforward, as are problems relative to portability of benefits across provincial boundaries. The point of contention is over who decides whether such practices constitute an infringement of the CHA principles and by how much in dollar terms. Here, there is not much room for dispute resolution. The minister of health decides and determines the dollar amount. There is a consultation process, but it works in a rather patriarchal fashion: the minister must inform the province of its "wrongdoing" and allow time for discussion, but the final enforcement decision is his or hers alone. In some cases, provincial governments have conferred with the federal government before implementing certain practices, thus voluntarily modifying them to avoid financial penalties. 
One could conclude that, most provinces, publicly at least, support the principles enunciated in the CHA: even with the sharp reduction in federal transfers in the 1990s, most provinces did not infringe the CHA standards; or at least, were not found to be doing so by the federal minister of health, who ultimately is responsible. In the 1996-97 fiscal year, for example, $\$ 2$ million was "docked" for violations, of which $\$ 1.3$ million was attributed to Alberta's allowance of facility fees (Manitoba accounted for $\$ 588,000$ in user fee deductions, while the rest was due to much smaller reductions to Nova Scotia and Newfoundland) (Maioni, "Decentralization").

\section{Challenge and Change in Health Care: Who Pays?}

Although health services in Canada are universal benefits, in fact there is no constitutional requirement for governments in Canada to offer such benefits to citizens. This is unlike, for example, some European countries where constitutional provisions set out the specific roles and responsibilities of central and regional governments in these matters (see Maino; Palier), or the European Constitution of 2004 that cites the "right of access to preventive health care and the right to benefit from medical treatment" under national laws. Instead, provincial statutes provide the framework for health care delivery and financing, while the Canada Health Act defines the standards by which the federal government participates in helping to finance health care services. These standards are at once more binding and less restrictive than exist in many other countries. They are explicit in banning certain initiatives; for example, those that impinge on equal access to care, such as user fees or extra billing. At the same time, however, these principles derive from a federal statute (not a formal constitutional requirement) and therefore the federal government is obliged to offer financial incentives (and the threat of financial penalty) to ensure provincial compliance.

Every legal resident of a Canadian province or territory is considered eligible for health care services, regardless of age or income, under the provincial health plan. In addition, health care benefits are considered portable across provincial boundaries. Most important in citizenship terms is the fact that health care services are to be allocated on the principle of equal access, the sole criterion being medical need, not ability to pay. Thus, unlike most other health care systems in the industrialized world, insured services are provided based on first-dollar coverage, without co-payments or user fees, and extra billing by doctors is prohibited.

Health care services are delivered through non-profit (voluntary) hospitals, fee-for-service professionals working individually or in a group practice, community clinics, home care, or long-term care facilities. Although providers and institutions are independent of direct state control, they remain dependent on political decisions about the allocation of resources. These 
decisions are made by provincial ministries, public medical commissions, or regional boards acting under the authority of the provincial government. Hospitals account for the largest share of health care spending and are financed by "global budgets" based on prospective analyses, negotiated with provincial governments. Public funds cover most of their operating costs (including medical supplies and equipment) and salaried employees (such as nurses and technicians staff) and hospitals are obliged to work within the budgets assigned to them for the fiscal year; in most provinces, hospitals are not permitted to run operating deficits. The provincial ministry of health sets these global budgets although, more recently, allocation decisions have become the responsibility of regional boards with a mix of representation from government, consumers, and providers.

Physician services, which account for about 14 percent of health care spending, are also financed through public funds. Doctors in Canada for the most part work on a fee-for-service basis, with a fee schedule negotiated between provincial governments and provincial medical associations. The reimbursement is administered by a public agency responsible to the provincial ministry of health. Although provincial governments do not directly regulate physician practices, they have attempted to shape physician behaviour in terms of fee structure and regional distribution of the work force. For example, some provinces tried to impose billing limits and salary caps on physicians and, in addition, offer differential fees to physicians with new billing numbers based on their practice and residence within the province.

Public responsibility for the financing of hospitals and reimbursement of medical care has become an onerous responsibility for provincial and federal governments. In Canada, provincial governments act as the "single-payer" or "single-tap" through which public money flows into the health care system. The public portion of health care financing (about 70 percent of total health care expenditures in Canada) is derived from general revenues and not a specific health insurance fund or tax. Health care accounts for the largest item in provincial budgets and most provinces spend at least 30 percent of their total outlays in this sector. All "medically necessary" services are supposed to be covered by public health insurance, including most diagnostics, in-patient hospital care and drugs, as well as all services billed for by physicians both in and outside the hospital. The private portion of health care spending is concentrated in expenditures for outpatient drugs, home and long-term care, and uninsured services: some diagnostics (such as MRIs), non-"medically necessary" surgery, or supplementary services. These include what are often considered essential services in other countries: for example, outpatient drug costs or dental care for adults. These uninsured services are paid for by outof-pocket payment or supplemental private insurance. 
Canada's health care spending now accounts for 10.4 percent of GDP, or about C $\$ 183$ billion (CIHI), making Canada a "big spender" in health care compared to other countries, but within the norm of its industrialized peers. There is regional variation, however: the average per person expenditure is about $\mathrm{C} \$ 5500$, but this varies from $\$ 4900$ in Quebec to $\$ 6000$ in Alberta, and in the northern territories, the average expenditure is well over $\$ 10,000$ per person.

Although provinces account for the lion's share of public funds that flow through the health sector, the provenance of these funds can vary across the country, from provincial general revenues garnered from income and corporate tax, natural resources royalties and consumption taxes, to payments from federal sources, such as transfer payments and equalization payments. While transfer payments are normally subject to the Canada Health Act, equalization payments (calculated through a formula based on provincial population and income) are not. Thus, although health care funding is "decentralized" to an important degree, allowing provinces significant latitude in the source and expenditure of funds, there remains a certain "dependence" on federal funding sources, which remain outside of the province's direct decision-making processes.

\section{Health Care Reform: Who Decides?}

The experience of past decades has shown that federal governments in Canada have used decentralization as a way of managing fiscal responsibilities as provincial governments shoulder an increasing responsibility for health care cost control. At the same time, however, federal governments have preserved important political space for themselves by retaining some measure of influence over the health policy-making agenda. Provincial governments, meanwhile, while still responsible for the costs of health care, are bound - symbolically and fiscally — by federal norms on how to spend health care money.

This has led to considerable political debate around whether fiscal federalism has constrained health reform in delivery or financing of services. While the Canada Health Act does not dictate how much should be spent in health care, it does condition in what way federal transfers should be spent. In addition, popular public sentiment reinforces the federal government's political clout in the health care sector.

One attempt at reconciling these tensions can be seen in the design of the Social Union Framework Agreement (SUFA) in February 1999 (signed by all the provinces except Quebec). Although this agreement was not specific to health care, its themes were directly relevant to health policy in acknowledging the need for more transparency and consultation in intergovernmental policy-making, including dispute resolution (Choudhry).The agreement acknowledged the need for more transparency and consultation in 
intergovernmental policy-making, including dispute resolutions. Although not specifically encompassing health care, the SUFA did suggest more collaboration between governments in a number of important health care areas - such as home-care and long-term care, physician labour management, improving mobility, commitments to Aboriginal health, and coordinating new initiatives such as capitation arrangements (i.e., physicians responsible for a fixed number of patient subscribers) or new technologies (Maioni, "The Social Union"). The SUFA also referred to ways in which citizens should "monitor" their health care system more effectively, through "public accountability and transparency" and the involvement of Canadians in "developing social priorities."

Such themes echo the idea of citizen engagement, a process by which governments encourage citizen participation in public policy-making. This engagement evokes the scenario of selected citizen participation in the definition of feasible alternatives to respond to specific problems in social policy (Abele et al.). Citizen engagement was one of the hallmarks of the Commission on the Future of Health Care in Canada (the Romanow commission), which relied heavily on input from citizen groups and individuals as it gathered information. The report itself emphasized the role of citizens in policy-making and in the essential values that Canadians have imbued in their health care system.

Through the 1990s, the theme of citizen engagement was also reflected in efforts to increase direct participation in decision-making processes for the delivery and allocation of services in the health care system. Many provinces moved toward the creation of regional health boards (some elected, others appointed, still others a mix of the two) as a way to decentralize decisionmaking, encourage population-based funding and other efficiencies, and empower citizens (Dorland and Davis). Although these initiatives sometimes implied a devolution of power from provincial health ministries to regional or local bodies that would have some measure of discretion in allocating health care resources, this was not always the case in implementation.

Part of the problem is that such boards were not always empowered to make what could be considered essential decisions, such as those related to specific fee setting or use of services. Questions were also raised as to what kinds of decisions such boards are equipped to make in terms of representation and accountability in the case of non-elected members and in terms of expertise for elected members. In practice, for example, professionals often outweigh community representatives in terms of their influence on boards. And, if important decisions are made that affect the delivery and use of health care for individuals and their families, then citizens in their communities ought to be informed and involved in making and supporting these decisions (Chin-Yee). 
In retrospect, the efforts toward citizen engagement may be problematic for at least three reasons: 1) specifically, because health care delivery and financing are part of a highly complex system that is difficult for non-experts to decipher; 2) more broadly, because effective engagement involves opening up a Pandora's box of new actors in the policy process, which can potentially widen the scope for conflict and make it difficult to achieve consensus; and 3) hypothetically, because attempts at inclusiveness can raise the potential for blame avoidance by governments and the off-loading of accountability between governments and citizens.

\section{The Emerging Role of the Courts in Health Care}

No discussion of citizenship and health care would be complete without mention of the role of the courts. The 1982 Charter of Rights and Freedoms has allowed a larger voice for the Supreme Court to define important aspects of citizenship rights in Canada and to protect the diversity of the Canadian social mosaic. One of the reasons that courts have taken on this role is that litigation provides very real advantages to individuals or groups trying to effect change; in other words, courts offer an alternative institutional passage that can circumvent the laborious and time-consuming policy channels that require knowledge of and access to bureaucratic and political decision-making (Manfredi "Judicial Power").

A growing jurisprudence in health care clearly illustrates this point. For example, two cases in British Columbia involved diversity and health care (see Manfredi and Maioni, "Courts"). In one case, a physician who moved to the province from Ontario protested the BC government's attempts to encourage doctors to practice outside of major urban centres by claiming that this interfered with her ability to practice her faith and thus violated her equality rights under the Charter. The $\mathrm{BC}$ court rejected this claim, but did agree that imposing limits on new doctors from outside the province did infringe on the mobility rights of Canadians under the Charter. In another case, a deaf and mute woman claimed that her access to health care had been jeopardized because there was no interpreter at the hospital to signal her needs to medical personnel. In this case, the Supreme Court agreed that her right to life, liberty, and security of the person had been violated and suggested that a remedy would be for $\mathrm{BC}$ hospitals to provide such services.

While these cases reflected how individuals are beginning to turn to legal channels to protect their rights against discrimination under the Charter, they also point to how courts are flexing new political muscle in health policymaking. Two landmark cases heard by the Supreme Court of Canada in 2004 seem to confirm these trends: Auton v. British Columbia and Chaoulliv. Quebec (see Manfredi and Maioni, "Judicializing"). In Auton, a group of parents of autistic children successfully sued the $\mathrm{BC}$ government to provide a 
controversial - and expensive - form of behavioural therapy. The BC courts agreed with their claims about discrimination, raising debate about the role of the courts in managing how duly elected governments should expend resources in health care. However, when the case was heard by the Supreme Court of Canada, the Court overturned the BC court judgement, stating that the "rights" of these children to this form of therapy was not guaranteed under the law.

In Chaoulli, the courts waded into one of the most explosive health reform debates in Canada: the role of private insurance in the health care system. In this case, a patient (Zeliotis) in Quebec who waited over a year for a hip replacement claimed that his security rights had been violated, and that the ban on private insurance in Quebec's health care laws had impeded his access to alternative forms of care in the private sector. The doctor (Chaoulli) meanwhile claimed that the ban and the restrictions on doctors who choose to leave the public system were discriminatory under the Charter. These claims were rejected by the Superior Court in Quebec, although the judge did interpret that there was a "right to health care" for citizens, but that this did not include the right to decide the "provenance" of one's health care.

When the Supreme Court rendered its decision on this case, it again overturned the lower court decisions. In an ironic twist, the majority decision argued that the ban on private insurance violated the Quebec charter of rights. If individual citizens were being denied their right to speedy medical services in the public system, the court claimed, the ban on private insurance (and private provision) could not be tolerated.

\section{Conclusion}

What emerges from an overview of the linkages between citizenship and health care in Canada is a paradoxical portrait on several levels. The rhetoric of a Canadian health care "system" belies the fact that health services are provided in the context of distinct provincial and territorial health care administrations. The federal presence in health care looms large in terms of the Canada Health Act, and yet the Act allows for considerable flexibility in terms of innovations in health care organization. Its symbolic function, however, remains considerable, in terms of the "trust" Canadians may allocate to the Canada Health Act and because of the federal government's continued financial presence in the health care sector through the transfers that are governed by the legislation. Still, CHA must be exercised in order to be effective, which means that future negotiations about funding levels between federal and provincial governments may open up further debate about the appropriateness and usefulness of the Canada Health Act.

Related to this is the discussion of nation-building and health care. While arguments can be made that the development of health care was part of a larger movement toward "national" and social citizenship, this is certainly a 
different story when told from the historical record in Quebec. The origins of heath care systems in Canada are a function of federalism, and so the conflicts that inhabit the federal-provincial relationship - such as the shared and divided identities, and debates over who pays and who decides - are part of the very essence of the relationship between health care and citizenship. There are also tangible ideological differences about the role of the state in society that have also had resonance in the development of provincial health care systems and the federal presence in this policy sector.

And, while the notion of regional equity infuses the perception of health care provision as a right of citizenship, the reality of regional discrepancies in quality and access to care, even within individual provinces, challenges this ideal. And, even though provincial governments attempted to decentralize and democratize health care, this has not been done with the kind of scope or science that is seen in health care jurisdictions elsewhere in the industrialized world. Regional health care agencies, with representation of "citizens" as well as experts and providers have been the chosen format but initial evidence suggests that there are significant limits to the democratic practices of these agencies. Moreover, a real downside is the risk that "democracy" is offered to compensate for reduced services and as a mechanism for making and justifying hard choices.

Finally, a rapid overview of the emerging role of the courts in health care underscores the essential debate at the heart of citizens' claims for protection under the Canadian Charter of Rights and Freedoms. It also reveals the potential fragility of the existing health care system in the face of pressures for privatization and commercialization. And it shows the way in which courts can impose national solutions on inherently local problems. In this particular instance, it further exacerbates growing tensions between Quebec and Ottawa over who is responsible for health care and who decides what the future of the system will look like. In the context of jurisdictional quarrels and money disputes that characterize federal-provincial relations in Canada, it remains to be seen whose institutional competence and which legislative arena is to have the final say in such important matters as health care reform for Canadian citizens.

\section{Works Cited}

Abele Francis, Katherine Graham, Alex Ker, Antonia Maioni, and Susan Phillips. Talking with Canadians: Citizen Engagement and the Social Union. Canadian Council on Social Development, July 1998.

Badgley, Robin F. "Health and Inequality: Unresolved Policy Issues." In Shankar A. Yelaja (ed.) Canadian Social Policy. Waterloo: Wilfred Laurier University Press (1987): 47-64. 
Banting, Keith. "The Welfare State as Statecraft: Territorial Politics and Canadian Social Policy.” European Social Policy: Between Fragmentation and Integration. Eds. S. Leibfried and P. Pierson, Brookings Institution, 1995.

Banting, Keith G., "The Past Speaks to the Future: Lessons from the Postwar Social Union." The State of the Federation 1997: Non-Constitutional Renewal. Ed. Harvey Lazar. Kingston: Institute of Intergovernmental Relations, Queen's University, 1998.

Daniel Béland and André Lecours, Nationalism and Social Policy: The Politics of Territorial Solidarity. Oxford: Oxford University Press, 2008.

Boothe, Paul, and Barbara Johnston. "Stealing the Emperor's Clothes: Deficit Offloading and National Standards in Health Care." Commentary, C.D. Howe Institute, No. 41, March 1993.

Canada. National Forum on Health, Canada Health Action: Building on the Legacy. Ottawa: Minister of Public Works and Government Services, 1997.

Canadian Institute for Health Information (CIHI). National Health Expenditure Trends, 1975 to 2009. Ottawa: 19 November 2009.

Castonguay, Claude. Mémoires d'un révolutionnaire tranquille. Montreal: Boréal, 2006.

Chin-Yee, Fiona. "Consumer Perspective." How Many Roads? Regionalization and Decentralization in Health Care. Eds. John L. Dorland and S. Mathwin Davis. Kingston: School of Policy Studies, Queen's University, 1996.

Choudhry, Sujit. "Bill 11, the Canada Health Act and the Social Union: The Need for Institutions." Osgoode Hall Law Journal 38 (2000): 40-99.

Commission on the Future of Health Care. Building on Values: The Future of Health Care in Canada, Final Report of the Commission. Ottawa: November 2002.

Dorland, John L. and S. Mathwin Davis, eds. "Regionalization as Health-Care Reform." How Many Roads?Regionalization and Decentralization in Health Care. Kingston: School of Policy Studies, Queen's University, 1996.

Esping-Andersen, Gøsta. "The Three Political Economies of the Welfare State." Canadian Review of Sociology and Anthropology 26:1 (1989): 10-35.

Evans, Robert G. Strained Mercy: The Economics of Canadian Health Care. Toronto: Butterworths, 1984.

Evans, Robert G. "Tension, Compression and Shear: Directions, Stresses and Outcomes of Health Care Cost Control." Journal of Health Politics, Policy and Law. 1990 Spring;15(1):101-128.

Facal, Joseph. Volonté politique et pouvoir médical. Montreal: Boréal, 2006.

Immergut, Ellen. Health Politics: Interests and Institutions in Western Europe. New York: Cambridge University Press, 1992.

Jenson, Jane. "Fated to Live in Interesting Times: Canada's Changing Citizenship Regimes." Canadian Journal of Political Science 30.4 (1997): 627-644.

Maino, Franca. La politica sanitaria. Milano: Il Mulino, 2001.

Maioni, Antonia. 1999. "Decentralization in Health Policy: Comments on A Convention On Canadian Economic And Social Systems" In Robert Young, ed., Stretching the Federation: The Art of the State in Canada, Kingston: Institute for Intergovernmental Studies. 
Maioni, Antonia. "Ideology and Process in the Politics of Social Reform." A New Social Vision for Canada? Perspectives on the Federal Discussion Paper on Social Security Reform. Eds. Keith Banting and Ken Battle. Kingston: School of Policy Studies, 1994: 117-123.

Maioni, Antonia. "New Century, New Risks: The Marsh Report and the Post-War Welfare State in Canada." Policy Options/Options politiques (August 2004): 20-23.

Maioni, Antonia. "Health Care in Canada." Canadian Federalism. $2^{\text {nd }}$ ed. Eds. Herman Bakvis and Grace Skogstad. Toronto: Oxford University Press, 2007.

Maioni, Antonia, "The Social Union and Health Care" Policy Options/Options Politiques, 21:3, 2000, pp. 39-41.

Manfredi, Christopher, and Antonia Maioni. "Courts and Health Policy: Judicial Policy Making and Publicly Funded Health Care in Canada." Journal of Health Politics, Policy and Law 27:2 (April 2002): 211-238.

Manfredi, Christopher, and Antonia Maioni. "Judicializing Health Policy: Unexpected Lessons and an Inconvenient Truth." Contested Constitutionalism: Reflections on the Canadian Charter of Rights and Freedoms. Eds. James B. Kelly and Christopher P. Manfredi. Vancouver: UBC Press, 2009: 129-144.

Manfredi, Christopher P. "Judicial Power and the Charter: Canada and the Paradox of Liberal Constitutionalism". Toronto: McClelland and Stewart, 1993.

Marshall, T. H. Citizenship and Social Class and Other Essays. Cambridge: Cambridge University Press, 1950.

Marsh, Leonard. Report on Social Security for Canada 1943. Toronto: University of Toronto Press, 1975.

Naylor, David C. Learning from SARS: Renewal of Public Health in Canada: A Report of the National Advisory Committee on SARS and Public Health. Ottawa: Health Canada, October 2003.

Palier, Bruno. La réforme des systèmes de santé. $4^{\text {th }}$ ed. Collection Que sais-je? Paris: Presses Universitaires de la France, 2009.

Scharpf, Fritz. "The Joint Decision-Making Trap: Lessons from German Federalism and European Integration." Public Administration 66:3 (1988): 230-278.

Smith, Miriam, and Antonia Maioni. "Health Care and Canadian Federalism." New Trends in Canadian Federalism. Eds. François Rocher and Miriam Smith. Peterborough: Broadview Press, 2003: 295-312.

Taylor, Malcolm G. Health Insurance and Canadian Public Policy: The Seven Decisions that Created the Canadian Health Insurance System and Their Outcomes. 2nd ed. Montreal: McGill-Queen's University Press, 1987.

Tuohy, Carolyn. "Conflict and Accommodation in the Canadian Health Care System." Medicare at Maturity: Achievements, Lessons and Challenges. Eds. Robert G. Evans and Greg L. Stoddart. Calgary: University of Calgary Press, 1989.

Weaver, R. Kent. “The Politics of Blame Avoidance.” Journal of Public Policy 6 (November 1986): 371-398. 